\title{
Penggunan E-Learning, E-Book, E-Journal dan Sistem Informasi Pendidikan Islam di Universitas Sriwijaya Palembang
}

\author{
Kasful Anwar Us \\ Pascasarjana UIN Sulthan Thaha Saifuddin Jambi \\ Email: kasfulanwarus@uinjambi.ac.id \\ Mahdayeni \\ IAI Nusantara Batanghari \\ Email: laangelina99@gmail.com
}

\begin{abstract}
The 4.0 industrial revolution in the field of education, universities must be able to respond to this by carrying out reforms and reforms, especially Islamic tertiary institutions so as not to lag behind western education by conducting E-Learning-based education, E-Book E-Journal and Islamic Education Information System (SIMPE) which is a form of educational products nowadays that prioritize information technology. Responding to the development of education, Sriwijaya University (UNSRI) has implemented an E-Learning-based education system, E-Book E-Journal and Simpe in its education system. E-Learning, E-Book E-Journal and SIMPE is a global issue in the world of education today, especially in university education. For this reason, the author focuses on the Implementation of E-Learning, E-Book E-Journal and SIMPE conducted by the Sriwijaya University Palembang.
\end{abstract}

Keywords: Digital Education: Universitas Sriwijaya.

\begin{abstract}
Abstrak: Menyongsong revolusi industri 4.0 dalam bidang pendidikan, perguruan tinggi harus mampu merespon dengan melakukan reformasi dan pembaruan terutama perguruan tinggi Islam agar tidak tertinggal dengan pendidikan barat dengan menyelenggarakan pendidikan berbasis E-Learning, E-Book E-Journal dan Sistim Informasi Pendidikan Islam yang merupakan bentuk produk pendidikan zaman now yang mengedepankan teknologi informasi. Merespon perkembangan pendidikan tersebut, Universitas Sriwijaya (UNSRI) telah menerapkan sistem pendidikan berbasis E-Learning, E-Book E-Journal dan Simpe dalam sistem pendidikannya. E-Learning, E-Book E-Journal dan Sistim Informasi Pendidikan Islam adalah isu-isu global dalam dunia pendidikan saat ini, terutama dalam pendidikan Perguruan Tinggi. Untuk itu penulis memfokuskan kepada Implementasi ELearning, E-Book E-Journal dan Simpe Pendidikan Islam yang dilakukan oleh Universitas Sriwijaya Palembang.

Kata-kata kunci: Pembelajaran digital; Universitas Sriwijaya.
\end{abstract}




\section{Pendahuluan}

Perkembangan Ilmu Pengetahuan dan Teknologi (IPTEK) yang kian pesat, serta perkembangan era globalisasi menuntut untuk dimanfaatkannya teknologi menggunakan internet dalam membantu mempermudah berbagai aktifitas manusia khususnya bidang pendidikan. Teknologi Informasi dan Komunikasi (TIK) dapat meningkatkan aktivitas pembelajaran dengan menyediakan bahan belajar dan meminimalisir keterbatasan terhadap waku serta tempat. Perwujudan Ilmu Pengetahuan dan Teknologi (IPTEK) harus disiapkan pada seluruh komponen baik dalam orientasi perilaku, sistem dan sikap dalam memanfaatkan TIK, dan cara berpikir. Sistem manajemennya yang meliputi; SDM, fasilitas, keuangan, sistem pembelajaran serta pengajaran yang pembangunannya dibangun secara padu. ${ }^{1}$

Dalam Al-Qur'an berkaitan dengan teknologi terdapat pada ayat yang memaparkan alam raya. Sebagaimana Qs. Al-Jatsyiah : 13 sebagai berikut:

Artinya : "dan Dia telah menundukkan untukmu apa yang di langit dan apa yang di bumi semuanya, (sebagai rahmat) daripada-Nya. Sesungguhnya pada yang demikian itu benar-benar terdapat tanda-tanda (kekuasaan Allah) bagi kaum yang berfikir." (Q.S. Al-Jatsyiah : 13). ${ }^{2}$

Saat ini, peranan teknologi dapat dirasakan secara nyata dan lebih luas di segala bidang, manusia berpotensi dalam memanfaatkan kekayaan alam raya sebaik mungkin jika potensi dan ketersediaan berbagai lahan tersebut dimanfaatkan dan mampu mengembangkan perintahnya. Keberhasilan dari termanfaatkannya alam itulah buah teknologi. ${ }^{3}$ Internet sebagai bagian dari teknologi informasi menjadi keniscayaan dan merupakan kebutuhan dalam bidang pendidikan, terutama di Perguruan Tinggi (PT). Sebagai suatu kebutuhan, kehadiran internet sangat membantu dunia pendidikan untuk mengembangkan situasi belajar mengajar yang kondusif dan interaktif. Salah satu peranan yang diberikan internet, yaitu sebagai salah satu media pembelajaran berbasis e-learning di Perguruan Tinggi. Elearning, E-Books banyak dijumpai dan telah diterapkan di beberapa Perguruan Tinggi di Indonesia.

Seiring dengan perkembangan zaman, tantangan dan hambatan pendidikan Islam juga terus mengalami perkembangan dan perubahan. Jika pada beberapa dekade silam percakapan akrab antara peserta didik dengan guru terasa tabu, maka hari ini justru merupakan hal yang wajar. Bahkan dalam pandangan teori pendidikan modern, hal itu merupakan sebuah keharusan. Interaksi semacam itu justru menjadi indikasi keberhasilan proses pendidikan.

\footnotetext{
1Munir, "Kontribusi Teknologi Informasi Dan Komunikasi (TIK) dalam Pendidikan di Era Globalisasi Pendidikan Indonesia", (Uurnal Pendidikan Teknologi Informasi Dan Komunikasi Ptik) Vol. 2 No. 2, Desember 2009), hal.1.

${ }^{2}$ Anonim, Al-Qur'an dan Terjemahan (Jakarta: Bumi Aksara, 2012), hal. 155.

3Yuberti, " Peran Teknologi Pendidikan Islam Pada Era Global", (Jurnal Akademika, Vol. 20 No. 01, 2016), hal. 2.
} 
Pergeseran paradigma lainnya misalnya dalam hal pendekatan pembelajaran. Pada era pendidikan Islam tradisional, pendidik menjadi figur sentral dalam kegiatan pembelajaran. Ia merupakan sumber pengetahuan utama di dalam kelas, bahkan dapat dikatakan satu-satunya. Namun dalam konteks pendidikan Islam modern, hal demikian tidak berlaku lagi. Peran guru hari ini telah mengalami pergeseran, yakni sebagai fasilitator bagi peserta didik. Pembelajaran tidak lagi berpusat pada guru (teacher centered), namun lebih berpusat pada peserta didik (student centered).

Pergeseran dan perubahan sebagaimana sedikit digambarkan di atas, merupakan keniscayaan yang tidak terelakkan. Hal ini disebabkan dari waktu ke waktu tuntutan dan kebutuhan manusia terus mengalami perubahan. Hari ini, pengetahuan luas saja tidak bisa menjamin seorang lulusan dapat bicara banyak dalam persaingan global. Diperlukan pula keahlian spesifik yang selaras dengan kebutuhan lapangan. Jika tidak demikian, maka lulusan pendidikan akan terlindas dan tersingkirkan. Lebih-lebih saat ini dunia telah memasuki era baru, yakni Era Revolusi Industri 4.0. Era Revolusi Industri 4.0 (selanjutnya: Era 4.0) membawa dampak yang tidak sederhana. Ia berdampak pada seluruh aspek kehidupan manusia. Termasuk dalam hal ini adalah pendidikan. Era ini ditandai dengan semakin sentralnya peran teknologi cyber dalam kehidupan manusia. Maka tak heran jika dalam dunia pendidikan muncul istilah "Pendidikan 4.0".

Pendidikan 4.0 (Education 4.0) adalah istilah umum digunakan oleh para ahli pendidikan untuk menggambarkan berbagai cara untuk mngintegrasikan teknologi cyber baik secara fisik maupun tidak ke dalam pembelajaran. Ini adalah lompatan dari pendidikan 3.0 yang menurut Jeff Borden mencakup pertemuan ilmu saraf, psikologi kognitif, dan teknologi pendidikan. Pendidikan 4.0 adalah fenomena yang merespons kebutuhan munculnya revolusi industri keempat dimana manusia dan mesin diselaraskan untuk mendapatkan solusi, memecahkan masalah dan tentu saja menemukan kemungkinan inovasi baru. ${ }^{4}$

Problematika internal dapat dilihat pada etos pendidikan Islam dewasa ini dilihat dari sistem pendidikan Islam yang dikelola UIN/IAIN/STAIN, PTAIS, dan sebagainya sesungguhnya cukup menggembirakan, atau bahkan jika tidak, jumlahnya melebihi kebutuhan sehingga over production, sementara ilmu-ilmu lain yang berorientasi kepada sains dan teknologi masih sangat langka. Maka logis bila ada asumsi yang menyatakan, "mahasiswa-mahasiswa Islam miskin akan wawasan, penguasaan sains dan teknologi, komunikasi, dan juga politik." Tidak salah bila disimpulkan bahwa etos pendidikan Islam sebagaimana yang ada sekarang masih kurang memperhatikan link and match dalam membangun sistem pendidikannya. ${ }^{5}$

${ }^{4}$ Eduaksi, Pendidikan 4.0, Apa Itu?, https://eduaksi.com/pendidikan-4-0-apa/, diakses 04 April 2019 pukul 09.17 WIB.

${ }^{5}$ Ahmad Barizi, (Ed), Pendidikan Integratif Akar Tradisi \& Integrasi Keilmuan Pendidikan Islam, (Malang: UIN-Maliki Press, 2011), hal.7 
Syamsul Ma"arif menyatakan bahwa pendidikan Islam saat ini, sungguh masih dalam kondisi yang sangat mengenaskan dan memprihatinkan. Pendidikan Islam mengalami keterpurukan jauh tertinggal dengan pendidikan Barat. Kalau boleh sedikit bernostalgia, pendidikan Islam tidak bisa seperti pada zaman keemasan (Andalusia dan Baghdad) yang bisa menjadi pusat peradaban Islam, baik bidang budaya, seni atau pendidikan. Yang terjadi justru sebaliknya, pendidikan Islam sekarang mengekor dan berkiblat pada Barat. Dengan supremacy knowledge yang dikuasai oleh negara-negara maju, negara-negara muslim masih terus bergantung kepada dunia Barat dalam hampir semua kehidupan: pertahanan dan persenjataan, komunikasi dan informasi, ekonomi, perdagangan, pendidikan dan pengembangan ilmu pengetahuan. ${ }^{6}$

Merujuk hasil penelitian dari McKinsey pada 2016 bahwa dampak dari digital tecnology menuju revolusi industri 4.0 dalam lima (5) tahun kedepan akan ada 52,6 juta jenis pekerjaan akan mengalami pergeseran atau hilang dari muka bumi. Hasil penelitian ini memberikan pesan bahwa setiap diri yang masih ingin mempunyai eksistensi diri dalam kompetisi global harus mempersiapkan mental dan skill yang mempunyai keunggulan persaingan (competitive advantage) dari lainnya. Jalan utama mempersiapkan skill yang paling mudah ditempuh adalah mempunyai perilaku yang baik (behavioral attitude), menaikan kompetensi diri dan memiliki semangat literasi. Bekal persiapan diri tersebut dapat dilalui dengan jalur pendidikan (long life education) dan konsep diri melalui pengalaman bekerjasama lintas generasi/lintas disiplin ilmu (experience is the best teacher). ${ }^{7}$

Berdasarkan kenyataan tersebut, maka perlu adanya perombakan atau reformasi di dalam tubuh pendidikan Islam. Pendidikan Islam di era 4.0 perlu untuk turut mendisrupsi diri jika ingin memperkuat eksistensinya. Mendisrupsi diri berarti menyesuaikan diri dengan kebutuhan dan tuntutan masyarakat serta berorientasi pada masa depan. Muhadjir Efendy dalam pidatonya mengatakan bahwa perlu ada reformasi sekolah, peningkatan kapasitas, dan profesionalisme guru, kurikulum yang dinamis, sarana dan prasarana yang andal, serta teknologi pembelajaran yang muktakhir agar dunia pendidikan nasional dapat menyesuaikan diri dengan dinamika zaman. ${ }^{8}$

Ketertinggalan pendidikan Islam selama ini, di samping disebabkan oleh problematika sebagaimana diuraikan sebelumnya, juga disebabkan oleh permasalahan laten yang tak kunjung menemui muara penyelesaian.

$1-2$

${ }^{6}$ Syamsul Ma"arif, Revitalisasi Pendidikan Islam, (Yogyakarta: Graha Ilmu, 2007), hal.

${ }^{7}$ Rosidin, Problematika Pendidikan Islam Perspektif Maqasid Shari'ah, Maraji': (Jurnal Studi Keislaman, Vol. 3, No. 1, September, 2016), hal. 186.

${ }^{8}$ Ranking Web of Universities edisi Januari 2018, dalam http://www.webometrics.info/en /Asia/indonesia\%20, diakses 10 April 2019. 
Rosidin ${ }^{9}$ mengungkapkan, ada empat faktor menyebabkan pendidikan Islam kerap mendapatkan kritik tajam. Cultural Lag atau gap budaya. Hal ini disebabkan terjadinya ketimpangan antara kecepatan perkembangan IPTEK dengan kecepatan perkembangan pendidikan. Laju akselerasi perkembangan IPTEK tersebut tidak diiringi dengan upaya pendidikan Islam untuk turut berakselerasi. Akibatnya, pendidikan Islam kurang responsif terhadap dinamika perubahan sosial masyarakat. Sehingga menjadi keniscayaan bila proses pendidikan di dalamnya menjadi kurang kontekstual. Stigma kelas dua. Faktor kedua ini dapat dikatakan sebagai akibat secara tidak langsung dari faktor pertama. Kelambatan pendidikan Islam dalam merespon dinamika perkembangan IPTEK dan realitas sosial menyebabkan stigma second class nyaman tersemat padanya.

Untuk menyongsong revolusi industri 4.0 dalam bidang pendidikan, maka perguruan tinggi harus mampu merespon hal tersebut dengan melakukan reformasi dan pembaruan terutama perguruan tinggi Islam agar tidak tertinggal dengan pendidikan barat dengan menyelenggarakan pendidikan berbasis E-Learning, E-Book E-Journal dan Simpe Pendidikan Islam yang merupakan bentuk produk pendidikan zaman now yang mengedepankan teknologi informasi.

Merespon perkembangan pendidikan tersebut, Universitas Sriwijaya (UNSRI) telah menerapkan sistem pendidikan berbasis E-Learning, E-Book E-Journal dan Simpe dalam sistem pendidikannya. Namun pendidikan berbasis ELearning, E-Book, E-Journal dan Simpe tersebut belum terkaksana dan berkembang dengan baik, seperti E-Learning yang belum berjalan dengan maksimal karena masih ada proses pembelajaran yang tidak berbasis ELearning. Masih terbatasnya E-Book yang disedakan oleh Universitas Sriwijaya (UNSRI), sehingga belum bisa memenuhi kebutuhan mahasiswa dan dosen. Masih rendahnya E-Jurnal yang dihasilkan oleh Universitas Sriwijaya (UNSRI). ${ }^{10}$

Berdasarkaan kegelisahan akademik sebagaimana yang telah penulis uraikan pada latar belakang diatas, maka penulis ingin melakukan penelitian lebih lanjut dengan judul "E-Learning, E-Book E-Journal dan Simpe Pendidikan Islam" (Studi Kasus pada Universitas Sriwijaya)".

\section{Pemanfaatan E-Learning}

E-learning adalah semua kegiatan pelatihan yang menggunakan media elektronik atau teknologi informasi. Sampai saat ini, pemakaian $e$ - learning sering digunakan untuk semua kegiatan pendidikan yang menggunakan media komputer atau internet. ${ }^{11}$ Hingga e-learning identik sekali dengan

${ }^{9}$ Rosidin, Problematika Pendidikan Islam Perspektif (Maqasid Shari'ah, Maraji': Jurnal Studi Keislaman, Vol. 3, No. 1, September, 2016), hal. 186.

${ }^{10}$ Observasi pada Universitas Sriwijaya (UNSRI) Palembang, 26 Februari 2019.

${ }^{11}$ Empi Effendy dan Hartono Zhuang, E-learning konsep dan aplikasi, (Yogyakarta: Andi, 2009), hal. 6-7 
media komputer dan internet. Melalui komputer peserta didik dapat belajar sendiri dengan terprogram ataupun tidak terprogram. Tidak terprogram seperti akses informasi di internet menggunakan mesin pencarian. ${ }^{12}$ Sejatinya komputer akan memudahkan dalam pembelajaran jika dibarengi dengan penggunaan internet.

Menurut Rusman, dkk e-learning terdiri atas dua bagian yakni e" singkatan dari 'electronica' dan 'learning' yang berarti „pembelajaran“. Sehingga e-learning berarti pembelajaran menggunakan bantuan perangkat elektronik seperti perangkat komputer atau perangkat lainnya. ${ }^{13}$ Perangkat elektronik banyak jenisnya, namun dalam e-learning lebih cocok menggunakan internet. Menurut Ali Mudlofir,dkk e-learning merupakan teknologi informasi dalam pendidikan dengan bentuk sekolah maya yang semua proses belajar mengajarnya dilakukan secara virtual denga materi yang bisa di download sendiri. ${ }^{14}$ Idealnya pembelajaran yang baik yakni yang membebaskan pembelajar dalam belajar. Sesuai dengan tersebut diatas pelajar mudah mendownload sendiri materi dan mengatur sendiri belajar virtualnya.

Banyak pula penggunaan terminologi yang memiliki arti hampir sama dengan e-learning. Web-based learning, online learning, computer- based training/ learnig, distance learning, computer-aided instruction, dan lain sebagainya, adalah terminologi yang sering digunakan untuk mengganti $e$ learning. Dalam praktiknya, e-learning sering diidentikkan dengan pendidikan jarak jauh. Dengan kata lain, pendidikan jarak jauh sama dengan e-learning. ${ }^{15}$

Pendapat di atas sejalan dengan pendapat Hamzah B.Uno pendidikan jarak jauh adalah sekumpulan metode pengajaran yang mana aktivitas pengajaran dilakukan dilakukan terpisah dari aktivitas belajar. Pemisahannya dapat berupa jarak fisik dan jarak non fisik. ${ }^{16}$ Pembelajaran yang baik adalah pembealajran secara tatap muka dan di dukung pembelajaran jarak jauh menggunakan internet sebagai pelengkap belajar. Pembelajaran jarak jauh ditandai dengan tidak adanya kontak berupa tatap muka langsung dan komunikasinya dijembatani dengan media seperti televisi, komputer, telepon, internet, radio, video dan sebagainya. ${ }^{17}$ Penulis sendapat dengan pendapat diatas yang menyatakan bahwa e-learning

\footnotetext{
12Daryanto, Media Pembelajaran, (Bandung: Satu Nusa, 2011), hal. 149

${ }^{13}$ Rusman, dkk, Pembelajaran Berbasis Teknologi Informasi dan Komunikasi, (Jakarta : PT RajaGrafindo Persada, 2011), hal. 60

${ }^{14}$ Ali Mudlofir, Desain Pembelajaran Inovatif dari Teori Ke Praktek, (Jakarta: PT RajaGrafindo Persada, 2016), hal. 174-175

15Dewi Salma Prawiradilaga, dkk, Mozaik Teknologi Pendidikan E-learning, (Jakarta : prenamedia group, 2013), hal. 28-44

${ }^{16}$ Hamzah dan Nina Lamatenggo, Teknologi Komunikasi dan Informasi Pembelajaran, (Jakarta: PT Bumi Aksara, 2011), hal. 103-169.

${ }^{17}$ Munir, Pembelajaran Jarak Jauh Berbasis Teknologi Informasi dan Komunikasi, (Bandung: Alfabeta, 2012), hal. 16
} 
memiliki makna yang sama dengan pendidikan jarak jauh, yakni tidak adanya kontak berupa tatap muka langsung dan komunikasi langsung.

Ada banyak terminologi pada kata e-learning, seperti virtual class, $e$ training, online learning, virtual learning, dan lain-lain. Tetapi, satu hal yang jelas, e-learning merupakan istilah generik dari pendayagunaan teknologi elektronik untuk pembelajaran. ${ }^{18}$ Banyak arti namun dapat disimpulkan dengan pendayagunaan alat elektronik untk belajar dalam kelas virtual menggunakan internet. Selain pendapat di atas, menurut Rusman, pembelajaran berbasis WBE (Web-Based Education) atau kadang disebut Elearning (electronic learning) diartikan sebagai aplikasi teknologi web dalam pembelajaran untuk menunjang proses pendidikan serta memanfaatkan internet selama proses belajarnya. ${ }^{19}$ Arti e-learning tidak hanya dipahami sebagai pembelajaran yang menggunakan alat elektronik seperti komputer dan lainnya saja, namun lebih luas dari itu, e-learning merupakan istilah generik dari pendayagunaan teknologi elektronik untuk pembelajaran.

Berdasarkan uraian tersebut peneliti dapat menyimpulkan bahwa $E$ laerning adalah semua kegiatan pelatihan yang menggunakan media elektronik atau teknologi informasi e-learning sering diidentikkan dengan pendidikan jarak jauh yang memanfaatkan internet selama proses belajarnya. Pendidikan jarak jauh sama dengan e-learning. E-learning merupakan istilah generik dari pendayagunaan teknologi elektronik untuk pembelajaran.

Karakteristik E-learning tidak sama dengan pembelajaran konvensional, memiliki karakteristik sebagai berikut :

a. Interactivity (Interaktivitas)

Jalur komunikasi yang lebih banyak baik secara langsung (synchronus), seperti messenger atau chatting dan tidak langsung (asynchronus), seperti mailing list, forum atau buku tamu.

b. Independency (Kemandirian)

Menyediakan fleksibilitas dalam waktu, pengajar, tempat, dan bahan ajar.Pembelajaran menjadi terpusat kepada peserta didik (student- center learning).

c. Accessibility (Aksesibilitas)

Mengakses sumber belajar menjadi mudah mendahui pendistribusian di jaringan internet dengan akses lebih luas dari pada pembelajaran konvensional.

d. Enrichment (Pengayaan)

Contoh pengayaan meliputi kegiatan pembelajaran, presentasi materi kuliah yang menggunakan penggunaan perangkat teknologi informasi seperti video streaming, simulasi, dan animasi. ${ }^{20}$

18Ibid., hal. 33

${ }^{19}$ Rusman, Model- Model Pembelajaran (Mengembangkan Profesionalisme Guru), (Jakarta : PT RajaGrafindo Persada, 2012), hal. 335.

${ }^{20}$ Ibid., hal. 264 
Dalam e-learning peserta didik mendapat pembelajaran tidak tergantung pada pendidik, bahan ajar yang disampaikan melalui interface situs web, serta sumber ilmu dapat diakses dengan mudah oleh setiap orang dikarenakan media internet yang mengglobal dan mudah diakses oleh siapa pun yang terkoneksi kedalamnya. Pengajar/lembaga pendidikan dalam $e$ learning berfungsi sebagai salah satu sumber ilmu pengetahuan. ${ }^{21} 25$ Sejatinya e-laerning akan lebih praktis dan efisien bila mudah diakses kapanpun dan dimanapun oleh pengaksesnya.

Sedangkan menurut Wina Sanjaya, Karakteristik dan konsep pembelajaran e-learning dan online yakni Perubahan Peranan Pendidik dengan memberikan pengarahan serta petunjuk untuk peserta didik dalam belajar sesuai gaya belajarnya dan Perubahan Pengelolaan Pembelajaran dengan mempelajari informasi sesuai topik bahasan. Peng elolaan lebih ke proses belajarnya. ${ }^{22}$ Gaya belajar akan mempengaruhi pembelajaran, sejatinya tipe belajar yang berbeda-beda jika dijadikan potensi akan menghasilkan solusi perbaikan untuk dapat dimengerti oleh masing-masing tipe belajar.

Pada dasarnya, e-learning mempunyai 2 tipe, yaitu synchronous dan asynchronous.

\section{1) Synchronous Training}

Synchronous berarti "pada waktu yang sama". Jadi, synchronous training adalah tipe pelatihan, dimana proses pembelajaran terjadi pada saat yang sama ketika pengajar sedang mengajar dan murid sedang belajar. Hal tersebut memungkinkan interaksi langsung antara pendidik dan peserta didik, baik melalui internet maupun intranet.

2) Asynchronus training

Asynchronus berarti " tidak pada waktu yang bersamaan". Jadi, seseorang dapat mengambil pelatihan pada waktu yang berbeda dengan pengajar memberi pelatihan. Keuntungan lebih bagi peserta pelatihan karena dapat mengakses pelatihan kapanpun dan dimanapun. ${ }^{23}$

Pelatihan berupa paket pelajaran yang dapat dijalankan dikomputer manapun dan tidak melibatkan interaksi dengan pengajar atau pelajar lain. Oleh karena itu, pelajar dapat memulai pelajaran dan menyelesaikannya setiap saat. Paket pelajaran berbentuk bacaan dengan animasi, simulasi, permainan edukatif, maupun latihan atau tes dengan jawabannya. E-learning umumnya selalu didefinisikan dengan penggunaan internet untuk menyampaikan pelatihan. Namun, saat ini, media penyampaian e-learning sangat beragam.

Lembaga Pendidikan yang memiliki laboratorium komputer menggunakan local area network (LAN) untuk menghubungkan komputer sebagai e-learning. Apabila ada situasi, dimana network komputer tidak

21 Ibid.

22 Wina Sanjaya, Media Komunikasi Pembelajaran, (Jakarta: Prenamedia Group, 2012), hal. 205-206.

${ }^{23}$ Empi Effendy dan Hartono Zhuang, Loc Cit., hal. 6-7. 
tersedia, e-learning dapat diberikan dalam media CD-ROM. Jadi, peserta dapat membawa CD-ROM dan memainkannya di komputer rumah maupun komputer di meja kantor. Sekarang para pendidik dapat merancang pembelajaran berbasis komputer dengan menggunakan bahasa pemrograman seperti delphi, macromedia flash, pascal, Swiss MX dan lainnya berkat munculnya berbagai software. ${ }^{24}$

Dalam penerapan e-learning, tenaga pendidik dan peserta didik memiliki perannya masing-masing. Tenaga pendidik (guru/dosen/instruktur ataupun widyaiswara) memiliki peran sebagai fasilitator dan pembimbing dalam kegiatan pembelajaran,sedangkan peserta didik (siswa dan mahasiswa) memiliki peran sebagai konstruktor pengetahuan, pembelajar mandiri (independent learners), dan pemecah masalah (problem solvers).

\section{Pemanfaatan $E$-Book}

Digital Book atau sering disebut E-Book (Electronic Book) dalam dunia pendidikan merupakan publikasi berupa teks dan gambar dalam bentuk digital yang diproduksi, diterbitkan, dan dapat dibaca melalui komputer atau alat digital lainnya. ${ }^{25}$ Digital Book merupakan buku elektronik dari sebuah buku tradisional dengan fitur digital yang dapat membantu pembaca dan merupakan alat yang menarik bagi kebanyakan peserta didik. Digital book menjadi bukti perkembangan teknologi canggih yang diharapkan dapat berkembang dari masa ke masa untuk memperbaharui buku kertas tradisional untuk masa depan prospektif. ${ }^{26}$

E-book merupakan bentuk digital dari sebuah buku yang berisi informasi tertentu. Buku elektronik memiliki format penyajian yang runtut, baik bahasanya, tinggi kadar keilmuannya, dan luas pembahasannya. ${ }^{27}$ Jika buku pada umumnya terdiri dari kumpulan kertas yang dapat berisikan teks atau gambar, maka buku elektronik berisikan informasi digital yang juga dapat berwujud teks atau gambar. ${ }^{28}$ Buku elektronik diminati karena ukurannnya yang kecil bila dibandingkan dengan buku, dan juga umumnya memiliki fitur pencarian, sehingga kata-kata dalam buku elektronik dapat dengan cepat dicari dan ditemukan. ${ }^{29}$ Buku elektronik atau electronic book

${ }^{24}$ Ibid., hal. 340.

${ }^{25}$ Muhammad Alwan, Pengembangan Multimedia E-Book 3D Berbasis Mobile Learning Untuk Mata Pelajaran Geografi SMA Guna Mendukung Pembelajaran Jarak Jauh,|| (Jurnal AtTadbir STAI Darul Kamal NW Kembang Kerang I, No. 2, 2018), hal. 29.

${ }^{26}$ Naimatil Jannah, Noor Fadiawati, and Lisa Tania, Pengembangan E-Book Interaktif Berbasis Fenomena Kehidupan Sehari-Hari Tentang Pemisahan Campuran,\|(Jurnal Pendidikan Dan Pembelajaran Kimia 6, No. 1, 2017), hal. 186-198.

${ }^{27}$ Aan Prabowo dan Heriyanto, Analisis Pemanfaatan Buku Elektronik (E-Book) oleh Pemustaka di Perpustakaan SMA Negeri 1 Semarang," (Jurnal Ilmu Perpustakaan Volume 2, Nomor 2, 2013), hal.13

${ }^{28}$ Wiji Suwarno, Library Life Style: Trend dan Ide Kepustakawanan, (Yogyakarta: Pustaka Nun Publishing, 2016), hal. 138.

${ }^{29}$ Ibid. 
atau e-book secara sederhana dapat dilihat dalam segala teks yang tersaji dalam bentuk dokumen yang dibuat dengan wordprocessor, HTML atau XML. Buku elektronik terdiri dari dua hal yaitu buku itu sendiri dan alat bacanya. ${ }^{30}$ Secara sempit, dapat juga dikatakan bahwa buku elektronik adalah buku cetak yang diubah-ubah menjadi elektronik untuk dibaca di layar monitor. ${ }^{31}$ Jadi, dapat disimpulkan bahwa buku elektronik merupakan bentuk digital dari sebuah buku yang tersaji dalam bentuk dokumen dalam bentuk wordprocessor, HTML atau XML. Dalam membaca buku elektronik tidak seperti buku tercetak karena dibutukan media khusus dalam membacanya yaitu layar monitor.

Dari pengertian tersebut dapat disimpulkan bahwa buku elektronik merupakan bentuk digital dari buku tercetak yang berisi ilmu pengetahuan dalam penyajiannya memiliki format tersendiri dan dibuat dengan wordprocessor, HTML atau XML. Tentunya karena buku tercetak dan buku elektronik mempunyai perbedaan maka pemustaka harus efektif dalam pemanfaatan buku elektronik tersebut. Dalam buku The Whole Digital Library Handbook disebutkan bahwa quality content is one of the key factors in providing an effective e-book model, ${ }^{32}$ yang artinya adalah kualitas isi daripada buku elektronik itu sendiri merupakan faktor utama dalam melihat model buku elektronik tersebut.

Tidak dapat dipungkiri bahwa buku elektronik mempunyai kelebihan dan kekurangan. Ida F Priyanto dan Sri P. Sedyaningsih ${ }^{33}$ menyebutkan bahwa adapun kelebihan -kelebihan tersebut terutama adalah dalam hal kegunaan (usability), kemudahan baca (readability), dan kemudahan penggunaan (ease of use) dalam kesehariannya. Selain memiliki kelebihan, buku digital beserta e-readernya juga memiliki kekurangan yang menjadikan produk tersebut tidak dapat memperoleh pasar yang baik terutama di Indonesia. Kelemahan tersebut adalah pada jumlah buku digital yang beredar di pasaran yang sesuai dengan alat baca yang kita miliki dan ketergantungan pada baterai.

Kelebihan pengembangan digital book ini antara lain:

a. Mudah dibawa karena berbentuk soft copy yang dapat digunakan pembaca dalam elektronik portable;

b. Tidak berat, digital book hanya perlu dimasukkan ke dalam folder di dalam elektronik portable, jadi yang dibawa hanya perangkat digital portable;

c. Mudah digandakan, digital book mudah untuk dicopy dengan gratis sehingga akan menghemat biaya dan akan mendukung kebutuhan belajar; 2008), 38.

${ }^{30}$ Pendit, PutuLaxman, Perpustakaan Digital dari A sampai Z (Jakarta: Cita Karya Karsa,

31 Ibid., hal. 40.

${ }^{32}$ Diane Kresh, The Whole Digital Library Handbook, (Chicago: American Library Association, 2007), hal. 278.

33Ida F Priyanto dan Sri P. Sedyaningsih, Buku Digital: Kajian Literatur Perkembangan dan Pengaruhnya pada Perpustakaan," (Jurnal Ilmu Perpustakaan dan Informasi., Vol.VIII, No. 2 Juli - Desember 2013), hal. 5-7. 
d. Hemat kertas, dalam era global warming berarti kita telah mendukung go green yang masih diusung pada masa kini. ${ }^{34}$

Dengan demikian, Digital Book merupakan pembaharuan buku tradisional menjadi buku digital dengan perpaduan beberapa media dan dengan desain semenarik mungkin tanpa mengesampingkan kegunaannya. $E$ book atau buku elektronik didasarkan pada karakteristik tradisional buku dalam format elektronik, serta dapat digunakan menggunakan teknologi internet agar membuat sebuah buku elektronik mudah dan efisien untuk digunakan. Buku elektronik dapat mengambil bentuk tunggal monografi atau multi-volume set buku-buku dalam format digital yang memungkinkan untuk melihatnya dalam berbagai jenis dengan monitor, perangkat, dan komputer.

\section{Penggunaan E-Journal}

Jurnal daring atau yang biasa juga disebut dengan jurnal elektronik adalah jurnal yang menyajikan karya-karya ilmiah yang dapat diakses melalui jaringan komputer dan internet. Jurnal dari kata journal (Bahasa Perancis) berarti catatan peristiwa dari hari ke hari. Jurnal dari kata journei (Bahasa Inggris) berarti catatan sidang-sidang parlemen dari hari ke hari. Penggunaan kata jurnal untuk berbagai bidang juga membawa arti yang bervariasi. Misalnya jurnal dalam bidang ekonomi menunjukkan sistem pembukuan rangkap. Jurnal dalam bidang pelayaran diartikan sebagai logbook berarti buku untuk mencatat semua kejadian selama pelayaran. ${ }^{35}$ Jurnal merupakan representasi dari pengetahuan baru tentang perkembangan ilmu pengetahuan yang dilaksanakan secara empiris dan biasanya merupakan gagasan yang terbaru. Sedangkan jurnal elektronik atau e-journal adalah jurnal yang segala aspek (penyiapan, review, penerbitan dan penyebaran) dilakukan secara elektronik. ${ }^{36}$

Jurnal sebenarnya merupakan publikasi ilmiah yang memuat informasi tentang hasil kegiatan dalam bidang ilmu pengetahuan dan teknologi minimal harus mencakup kumpulan/kumulasi pengetahuan baru, pengamatan empiris dan pengembangan gagasan atau usulan. Dengan demikian, jurnal merupakan representasi dari pengetahuan baru tentang perkembangan ilmu pengetahuan yang dilaksanakan secara empiris dan biasanya merupakan gagasan yang terbaru. Sedangkan jurnal elektronik atau e-journal adalah jurnal yang segala aspek (penyiapan, review, penerbitan dan penyebaran) dilakukan secara elektronik. ${ }^{37}$

Dari beberapa pengertian di atas, penulis dapat menarik kesimpulan bahwa, jurnal elektronik adalah jurnal yang dalam bentuk penyajian dan

${ }^{34}$ Yusnimar, E-Book Dan Pengguna Perpustakaan Perhuruan Tinggi Di Jakarta,ll (Jurnal Al-Maktabah 13, No. 1, 2014), hal. 34-39. hal. 129.

${ }^{35}$ Lasa HS , Kamus Pustakawan Indonesia, (Yogyakarta: Pustaka Book Publisher, 2009),

${ }^{36}$ Arif Nurochman, Strategi Digital untuk Meningkatkan Pemanfaatan E- Journal: Perspektif Pustakawan dan Perpustakaan, (Jurnal Visi Pustaka, Vol.13, 2011), hal. 12

${ }^{37}$ Ibid. 
penyebarannya kepada para pemustaka disajikan dalam bentuk elektronik, baik dalam bentuk CD ROM, disket atau media penyimpanan elektronik lainnya.

Peran jurnal online dalam pengembangan ilmu pengetahuan di era Google saat ini telah memberikan kontribusi yang besar bagi lembagalembaga pendidikan tinggi di tanah air. Ini telah menjadi kebutuhan utama pada tiap-tiap lembaga tinggi untuk menyediakan atau berlangganan jurnal-jurnal, baik dalam dan luar negeri, demi meningkatkan atau memperluas wawasan para civitas akademik.

Dalam dunia ilmu pengetahuan telah terjadi serbuan informasi dari para produsen informasi, berupa buku teks, jurnal, laporan penelitian, makalah seminar ilmiah, konferensi internasional maupun informasi yang dikemas secara elektronik. ${ }^{38}$ Demikian juga dalam beberapa tahun terakhir ini, penelusuran informasi elektronik dan digital telah berkembang dengan sangat cepat, mulai dari koran, jurnal dan majalah ilmiah.

Jurnal elektronik dapat dibedakan menjadi 2 kelompok dari segi akses, yaitu:

a. Jurnal elektronik dapat diakses tanpa adanya biaya dan dapat didownload lalu dicetak dengan bebas (open access);

b. Jurnal elektronik tidak dapat diakses bila tidak melanggannya dan menggunakan password untuk mengaksesnya (closed access). Pendapat lain tentang jenis jurnal elektronik, yaitu: (1) jurnal yang terbit hanya dalam bentuk elektronik (electronic-only journal); (2) jurnal versi elektronik dengan versi cetakannya. ${ }^{39}$

Jurnal elektronik yang dapat diakses dengan open access merupakan sebuah jurnal yang berisi sumber informasi yang memungkinkan pengguna untuk mengkases karya ilmiah secara gratis. Jurnal elektronik yang tersedia secara online, siapapun di seluruh dunia dapat mengkasesnya tanpa hambatan baik dalam masalah legal maupun teknis. ${ }^{40}$ Adapun jurnal online closed access merupakan sebuah jurnal yang dilanggan oleh sebuah instansi atau badan dan dalam mengkasesnya membutuhkan username atau password untuk mengkases jurnal tersebut.

Ada juga jurnal elektronik yang dapat dibedakan menurut bentuk pengirimannya, mengidentifikasi adanya tiga bentuk penerbitan jurnal elektronik, yaitu:

1) Jurnal elektronik adalah jurnal yang terpasang melalui komputer utama seperti Bibliographic Retrieval Services;

2) Jurnal pada CD-ROM adalah jurnal yang berbentuk teks penuh atau jurnal yang dikoleksi dari berbagai subjek jurnal tercetak yang ada, dan versi

\footnotetext{
${ }^{38}$ Sawitry, N. D, Pemanfaatan Koleksi E-Journal Bidang Ekonomi dan Bisnis oleh Civitas Akademika pada Perpustakaan Fakultas Ekonomi dan Bisnis (FEB) UIN Syarif Hidayatullah Jakarta. Skripsi, (Jakarta: UIN Syarif Hidayatullah, 2011), hal 30.

${ }^{39}$ Etty Andrianty, Pemanfaatan Jurnal Elektronis dan Kemuktahiran Informasi yang Disitir dalam Publikasi Primer", (Jurnal Perpustakaan Pertanian, 14, No. 2 2005), hal. 26.

${ }^{40}$ Azwar, Information Literacy Skills: Strategi Penelusuran Informasi Online, 149.
} 
elektroniknya ditempatkan pada CD-ROM;

3) Jurnal pada network adalah jurnal dalam bentuk jaringan kerja yang didasarkan pada perangkat lunak mailing list atau aplikasi komputer klien atau server yang termasuk di dalamnya, seperti: Gopher, FTP, dan World Wide Web $(w w w)$ pada situs web internet. ${ }^{41}$

Menurut Reitz (2004) dalam Online Dictionary of Library Information Science, sumber referensi adalah: Any publication used by a reference librarian to provide authoritative information in response to a reference question, including but not limited to reference books, catalog records, printed indexes and abstracting services, and online bibliographic databases. Individuals and services outside the library who can be relied upon to provide authoritative information are considered resources for referral ${ }^{42}$

Publikasi yang digunakan pustakawan sebagai referensi untuk memberikan informasi dalam menanggapi pertanyaan, tidak terbatas hanya buku referensi, tetapi juga catatan katalog, indeks dan abstrak, serta pangkalan data online. Layanan di luar perpustakaan dapat diandalkan untuk memberikan informasi yang dapat dianggap sebagai bahan rujukan.

Sumber referensi digital dapat berupa buku elektronik dan jurnal elektronik. Sumber informasi berbasis internet tersedia sepanjang waktu, terlepas dari waktu buka perpustakaan, dan tidak rentan terhadap pencurian atau kerusakan, serta mudah diperbaruhi oleh penerbit, dan internet merupakan sumber utama mahasiswa dalam pencarian informasi. Untuk sumber referensi, ketersediaan informasi yang mutakhir sangat dibutuhkan oleh para peneliti. Informasi pada jurnal elektronik yang lebih mutakhir berisi artikel- artikel dari hasil penelitian yang terbaru dan aktual. ${ }^{43}$

Sumber referensi elektronik tetap mempertahankan karakteristik dari referensi tercetaknya. Jurnal elektronik dapat dijadikan akses bagi perpustakaan perguruan tinggi dalam meningkatkan pelayanan terhadap koleksi digital untuk penggunanya. Pemanfaatan jurnal elektronik sebagai sumber referensi dalam penulisan skripsi membuat nilai tambahan informasi yang relevan tentang penelitian yang diambil.

Ada beberapa kelebihan dan kekurangan dari pemanfaatan jurnal elektronik. Adapun kelebihan dari pemanfaatan jurnal elektronik adalah:

a) Kecepatan (speed), artikel dapat segera diletakkan di web tanpa menunggu waktu lama lagi.

b) Penelusurannya mudah (easily searchable), merupakan keuntungan utama dalam format digital.

c) Interaktif (interactive), kemudahan dalam mengakses artikel yang langsung dibaca dan juga dicetak (printed) jika dibutuhkan.

\footnotetext{
${ }^{41} \mathrm{H}$. Woodward, Cafe Jus: an Electronic Journals User Survey", Oournals of Digital Information, 1, No. 31998).

${ }^{42}$ Reitz, ODLIS: Online Dictionary of Library and Information Science, 564.

${ }^{43}$ Andrianty, Pemanfaatan Jurnal Elektronis dan Kemuktahiran Informasi yang Disitir dalam Publikasi Primer", hal.28.
} 
d) Aksesibilitas (accessible), akses melalui internet merupakan salah satu cara akses yang berbeda dengan jurnal tercetak. Beberapa pengguna dapat mengakses jurnal elektronik secara bersamaan.

e) Links, merupakan kaitan antara satu artikel dengan artikel lainnya yang disitir (hypertext format).

f) Nilai tambah (added value), merupakan kelebihan lainnya dari jurnal elektronik yaitu dapat menggunakan animasi, virtual reality dan diagram matematik interaktif (interactive mathematical charts). "

g) Murah (inexpensive), menggunakan jurnal elektronik telah mengurangi biaya sebanyak $70 \%$ dibandingkan apabila membeli jurnal tercetak.

h) Fleksibel (flexibility), dengan menggunakan jurnal elektronik tidak tergantung dengan format, printer atau jaringan distribusi yang selalu melekat dengan jurnal tercetak (Siswadi, 2008).

i) Fleksibel (flexibility), dengan menggunakan jurnal elektronik tidak tergantung dengan format, printer atau jaringan distribusi yang selalu melekat dengan jurnal tercetak. ${ }^{44}$

Selain kelebihan di atas, juga dipaparkan beberapa kekurangan dari pemanfaatan jurnal elektronik, yaitu:

1) Kesulitan membaca layar komputer (difficulty reading computer screens).

2) Sering tidak memasukkan indeks dan abstrak (often not included in indexing and abstracting services). Pada umumnya artikel yang terdapat pada jurnal elektronik menyediakan keduanya, tetapi ada juga yang tidak melengkapi salah satunya.

3) Sitasi yang mudah rusak (perishable citation), perubahan URL menjadikan akses ke jurnal elektronik menjadi terganggu bahkan hilang.

4) Keaslian (authenticity), sumber dan otoritas material secara umum menjadi perhatian pada akses jurnal elektronik. Kredibilitas pembacanya selalu harus diperhatikan.

5) Mesin pencari mengabaikan file PDF (search engines ignore PDF files), perlu memperhatikan format dari artikel jurnal elektronik. Format yang tersedia merupakan copy dari versi jurnal tercetaknya. ${ }^{45}$

Jika dalam pembelajaran dikatan efektif apabila peserta didik secara aktif dilibatkan dalam pengorganisasian dan penerimaan informasi pengetahuan, maka menurut penulis pemanfaatan jurnal elektronik dikatakan efektif apabilah seluruh civitas yang ada dalam ruang lingkup perguruan tinggi (mahasiswa, dosen dan civitas akademika) telah memanfaatkan jurnal elektronik yang disediakan oleh perguruan tinggi.

\footnotetext{
${ }^{44}$ Siswadi, Irman. Ketersediaan Online Journals di Perpustakaan Perguruan Tinggi". Visi Pustaka. Vol.10, No.2, 2008.

${ }^{45}$ Ibid.
} 


\section{Sistem Informasi Manajemen Pendidikan}

Sistem informasi manajemen merupakan sebuah sistem informasi yang selain melakukan pengolahan transaksi yang sangat berguna bagi kepentingan organisasi, juga banyak memberikan dukungan informasi dan pengolahan untuk fungsi manajemen dalam pengambilan keputusan. ${ }^{46}$ Menurut Stoner, sistem informasi manajemen adalah sebuah metode formal untuk menyediakan informasi yang akurat dan tepat waktu bagi manajemen yang diperlukan untuk mempermudah proses pengambilan keputusan, dan memungkinkan fungsi-fungsi dari manajemen seperti perencanaan, pengendalian, dan operasional organisasi dapat dilaksanakan secara efektif.

Sistem informasi manajemen adalah suatu aktifitas organisasi, kebutuhan mengenai proses pengembangan yang akan terjadi, dengan menyelenggarakan pendidikan sesuai arah dan strategi dan merupakan faktor yang sangat penting begitu makanya bisa dikatakan pentingnya nilai informasi bagi organisasi. Dalam kehidupan suatu negara, pendidikan memegang peranan yang penting karena pendidikan merupakan wahana untuk meningkatkan dan mengembangkan kualitas sumber daya manusia. Untuk menyelenggarakan pendidikan sesuai arah dan setrategi yang ditetapkan sekaligus menjawab tuntutan organisasi pendidikan memasuki era global, maka manajemen pendidikan memerlukan suatu sistem informasi yang mampu menjangkau semua struktur dan elemen pendukung lainya. ${ }^{4}$

Menurut George M. Scott, sistem informasi manajemen adalah sekumpulan sistem informasi yang saling berinteraksi, yang memberikan informasi baik untuk kepentingan operasi atau kegiatan manajerial. ${ }^{48}$ Menurut Ais Zakiyudin dalam bukunya bahwa, sistem informasi manajemen adalah suatu sistem informasi manajemen menggambarkan ketersediaan suatu rangkaian data yang cukup lengkap yang disimpan agar dapat menyediakan informasi untuk mendukung operasi, manajemen, dan pembuatan keputusan dalam suatu organisasi. ${ }^{49}$

Berdasarkan defenisi para ahli, maka dapat disimpulkan bahwa, sistem informasi manajemen adalah suatu sistem yang dirancang untuk menyediakan informasi guna mendukung pengambilan kepetusan pada kegiatan manajemen dalam suatu organisasi. Dengan mengacu kepada pengertian sistem informasi manajemen maka dapat disimpulkan bahwa konsep sistem informasi manajemen memiliki beberapa karakteristik yaitu:

a. Dalam suatu organisasi terdapat satu bagian khusus sebagai pengelola sistem informasi manajemen

${ }^{46}$ B. Siswanto, Pengantar Manajemen, (Jakarta: Bumi Aksara 2011), hal. 188

${ }^{47}$ Onisimus Amtu, Manajemen Pendidikan di Era Otonomi Daerah, (Bandung : Alvabeta, 2013), hal. 1.

${ }^{48}$ Scott, George M. Prinsip-prinsi Sistem Informasi Manajemen. (Jakarta: PT.Rajagafindo Persada 2011), hal. 69.

${ }^{49}$ Ais Zakiyudin, Sistem Informasi Manajemen. (Jakarta: Mitra Wacana Media 2011), hal. 15 
b. Sistem informasi manajemen merupakan jalinan lalu lintas data dan informasi dari setiap bagian didalam organisasi yang terpusat dibagian sistem informasi manajemen

c. Sistem informasi merupakan jalinan hubungan antar bagian dalam organisasi melalui satu bagian sistem informasi manajemen

d. Sistem informasi manejemen merupakan segenap proses yang mencangkup: pengumpulan data, pengolahan data, penyimpanan data, pengambilan data, dan penyebaran informasi dengan cepat dan tepat.

e. Sistem informasi bertujuan agar para pelaksana dapat melaksanakan tugas dengan baik dan benar serta pimpinan dapat membuat keputusan dengan cepat dan tepat. ${ }^{50}$

Untuk dapat memanfaatkan sistem informasi dengan efektif, maka harus diketahui dengan pasti tentang organisasi, manajemen, dan teknologi organisasi yang membentuk sistem. Berikut ini dijelaskan elemen-elemen sistem informasi manajemen: Elemen Pertama, yaitu organisasi meliputi manusia, struktur, prosedur operasi, politik, dan kultur. Elemen Kedua, yaitu manajemen, mengamati kesempatan, membuat strategi untuk menjawab kebutuhan, mengalokasikan orang dan sumber dana untuk mendukung strategi yang telah dibuat, mengkoordinasikan pekerjaan atau kegiatan dalam organisasi. Elemen Ketiga, yaitu teknologi informasi yang merupakan alat yang dapat digunakan oleh manajemen untuk membantu melakukan kontrol dan membuat suatu kegiatan baru. Teknologi terdiri atas tiga komponen pokok, yaitu manusia (brainware),perangkat keras (hardware), dan perangkat lunak (software), yang digunakan membantu menerima masukan (input), mengolah, dan mengeluarkan hasil (ourput), serta dapat dipakai untuk meneyebarluaskan hasil olahan atau analisi. ${ }^{51}$

Tujuan dibentuknya sistem informasi manajemen adalah supaya organisasi memiliki suatu sistem yang dapat diandalkan dalam mengolah data menjadi informasi yang bermanfaat dalam pembuatan keputusan manajemen, baik yang menyangkut keputusan-keputusan rutin maupun keputusan-keputusan strategik. Dengan demikian Sistem Informasi Manajemen adalah suatu sistem yang menyediakan kepada pengelola organisasi data maupun informasi yang berkaitan dengan pelaksanaan tugas-tugas organisasi. ${ }^{52}$

Tujuan dari dibangunnya informasi berupa aplikasi sistem informasi pendidikan adalah:

1) Membantu seluruh bagian yang berperan di dunia pendidikan dengan memberikan informasi yang menyeluruh tentang pendidikan dari tingkat sekolah dasar hingga sekolah menengah umum atau yang setara dengannya.

50Suryadi, Manajemen Pendidikan, (Bandung: Alfabeta, 2011), hal. 166-167.

51Afifuddin, Dasar-Dasar Manajemen, (Bandung: Alfabeta, 2013), hal. 237.

${ }^{52}$ Wahyudi Kumorotomo dan Subando Agus Margono, Sistem Informasi Manajemen, (Yogyakarta: Gadja Mada University Press 2009), hal. 13. 
2) Pertanggungjawaban publik yaitu dengan memberikan informasi secara transparan tentang kebijakan dan pemakaian sumber daya yang dialokasikan untuk dunia pendidikan.

3) Memberi sarana agar seluruh bagian yang berperan dalam dunia pendidikan yang ada di propinsi/kota kabupaten agar dapat berperan aktif dalam usaha memajukan usaha pendidikan.

4) Meningkatkan pengetahuan pendidik dan peserta didik tentang dunia informatika serta manfaat yang dapat diambil melalui beberapa pelatihan.

5) Memberikan akses informasi yang mudah dan lengkap bagi pendidik dan peserta didik mengenai ilmu pengetahuan dan informasi pendidikan lainnya.

Maksud dilaksanakannya sistem informasi manajemen pendidikan adalah, sebagai pendukung kegiatan fungsi manajemen dalam rangka menunjang tercapainya sasaran dan fungsi-fungsi operasional dalam organisasi pendidikan. Dengan adanya sistem informasi manajemen pendidikan, organisasi pendidikan akan merasakan beberapa manfaat sebagai berikut, yaitu: pertama, tersedianya sistem pengelolaan data dan informasi pendidikan. Kedua, terintegrasinya data dan informasi pendidikan untuk mendukung proses pengambilan keputusan. Ketiga tersedianya data dan informasi pendidikan yang lengkap bagi seluruh stakholders yang bergabung dalam bidang pendidikan.

\section{Penutup}

Perkembangan Teknologi Informasi dan Komunikasi (TIK) telah mempengaruhi semua aspek yang ada, seperti aspek ekonomi, budaya, politik, sosial, pertahanan keamanan, pekerjaan rumah tangga bahkan dunia pendidikan sekalipun. Melihat peran penting TIK dalam pembelajaran, maka pada pelaksanaannya banyak sekali model pembelajaran yang telah dikembangkan untuk memecahkan masalah belajar dan pembelajaran. Salah satu model tersebut ialah model pembelajaran berbasis Teknologi Informasi dan Komunikasi (TIK). Model pembelajaran TIK banyak melahirkan istilah seperti web-based learning, online learning, distance learning, e-learning, ebooks, e-jurnal, dan sistem informasi manajemen.

Berdasarkan pada tujuan penelitian yang disebutkan sebelumnya, penelitian ini secara khusus meneliti penerapan e-learning, e-books, e-jurnal dan sistem informasi manajemen yang diterapkan oleh Universitas Sriwijaya Palembang. Keberadaan e-learning, e-books, e-jurnal dan sistem informasi manajemen dalam sistem perguruan tinggi menjadi isu global saat ini, pemanfaatan e-learning, e-books, e-jurnal dan sistem informasi manajemen dalam sistem pendidikan pada perguruan tinggi menjadi formulasi baru dalam dunia pendidikan perguruan tinggi. Karena dengan adanya e-learning, e-books, e-jurnal dan sistem informasi manajemen dalam penyelenggaraan pendidikan pada perguruan tinggi dapat berdampak peningkatan kualitas pendidikan secara signifikan. 
Rektor Universitas Sriwijaya Palembang menjelaskan bahwa keberadaan e-learning, e-books, e-jurnal dan sistem informasi manajemen dalam sistem pendidikan pada perguruan tinggi saat ini tidak bisa dipisahkan, dengan memanfaatkan perkembangan teknologi dan informasi seperti saat ini maka perguruan tinggi dituntut untuk dapat menyesuaikan diri dengan perkembangan tersebut. Merespon perkembangan teknologi dan informasi tersebut, universitas Sriwijaya Palembang telah menerapkan sistem e-learning, e-books, e-jurnal dan sistem informasi manajemen. Lebih lanjut Rektor Universitas Sriwijaya Palembang menjelaskan keberadaan $e$ learning, e-books, e-jurnal dan sistem informasi manajemen dalam sistem pendidikan pada Universitas Sriwijaya ini menjadi sebuah keharusan, untuk itu Universitas Sriwijaya telah menanfaatkan e-learning, e-books, e-jurnal sebagai sumber belajar serta menanfaatkan serta sistem informasi manajemen dalam melakukan tata kelola Universitas Sriwijaya. ${ }^{53}$

Berdasarkan obervasi yang penulis lakukan pada Universitas Sriwijaya Palembang, memang e-learning, e-books, e-jurnal dan sistem informasi manajemen telah diterapkan dalam sistem pendidikan Universitas Sriwijaya Palembang. Namun berdasarkan hasil penelusuran penulis penerapan $e$ learning, e-books, e-jurnal dan sistem informasi manajemen belum maksimal. Hal ini dapat dilihat masih banyak proses pembelajaran yang dilakukan secara tatap muka, masih minimnya e-books yang bisa diakses oleh mahasiswa, masih mimimnya jurnal yang tersedia yang bisa diakses oleh mahasiswa mapun dosen. ${ }^{54}$

Wawancara penulis dengan Rektor Universitas Sriwijaya Palembang yang menjelaskan dalam penyelenggaraan e-learning, e-books, e-jurnal dan sistem informasi manajemen melakukan serangkaian analisis terlebih dahulu. Salah satu analisis yang dilakukan ialah mempertimbangkan kelayakan dan kebutuhan e-learning pada Universitas Sriwijaya. Analisis kelayakan dan kebutuhan memang tidak secara resmi dilakukan, di mana tim pengembang melakukan uji coba kepada mahasiswa baik dalam skala kecil maupun besar. Hasil analisis yang diperoleh dari uji coba tersebut bahwa Universitas Sriwijaya sudah sesuai aspek teknisnya namun ada beberapa catatan yang harus diperhatikan yaitu budaya belajar dalam perkuliahan secara elektronik dan budaya kemandirian belajar mahasiswa yang masih rendah. 55

Selanjutnya Rektor Universitas Sriwijaya juga menjelaskan bahwa di luar dari analisis kebutuhan dari mahasiswa, analisis kelayakan juga dilakukan dengan cara mempertimbangkan sarana dan prasarana. Universitas Sriwijaya dalam melaksanakan uji kelayakan seperti mempertimbangkan jumlah mahasiswa dengan kondisi kelas, sedangkan dari

53Wawancara dengan Anis Saggaff, Rektor Universitas Sriwijaya Palembang, 26 Februari 2019.

$\mathrm{Pe}$

55Wawancara dengan Anis Saggaff, Rektor Universitas Sriwijaya Palembang, 26 Februari 2019. 
sisi sarana, jurusan ini juga sudah menguji keadaan jaringan, hardware, dan software penunjang perkuliahaan e-learning. Dari sisi keilmuan, Universitas Sriwijaya menjaga sekali keilmuan dengan cara melakukan serangkaian kajian terhadap platform (software) dan materi berdasarkan lingkup keilmuan Teknologi Pendidikan. Hasil uji coba yang sudah dilakukan membawa dampak bahwa memang sudah saatnya e-learning harus diterapkan di Rektor Universitas Sriwijaya. ${ }^{56}$

Kepala Biro Universitas Sriwijaya Palembang memberikan penjelasan bahwa pelaksanaan pembelajaran pada Universitas Sriwijaya Palembang memang tidak sepenuhnya secara e-learning, karena tidak semua materi dapat dionlinekan. Ada aktivitas analisis materi yang dilakukan. Aktivitas ini dilakukan dengan cara identifikasi mata kuliah yang topiktopiknya sesuai dilaksanakan melalui e-learning. Analisis materi dilakukan oleh dosen pengampu, tim pengembang, dan rekan sejawat melalui Chunks of Contents untuk diisi dalam Learning Paths berdasarkan ragam pengetahuan dan hanya pemilihan mata kuliah yang memiliki kognitif tinggi saja. Analisis juga dilakukan melalui pertimbangan ragam pengetahuan dari suatu materi. Prosesnya dengan mempelajari tujuan pembelajaran lalu mempertimbangkan apakah tujuan pembelajaran tersebut dapat dicapai dengan menggunakan konsep e-learning. Hasil dari analisis materi diperoleh sejumlah mata kuliah yang sesuai untuk dikembangkan melalui e-learning. Materi yang dikembangkan juga sangat bergantung pada dosen pengampunya. ${ }^{57}$

Pernyataan diatas dapat dipahami bahwa sebelum menerapkan sistem pembelajaran E-Learnng, Universitas Sriwijaya Palembang terlebih dahulu malkukan analisis untuk mengetahui sejauhmana kesiapan mahasiswa maupun dosen untuk melaksankaan sistem pembelajaran berbasis $E$ Learning. Dan hasilnya menunjukkan bahwa tidak semua mata kuliah bisa dilakukan dengan E-Learning, selain dari pada itu tidak semua dosen pada Universitas Sriwijaya ini siap untuk melaksanakan pembelajaran E-learning.

Selanjutnya pada Universitas Sriwijaya Palembang, penggunaan e-book juga masih belum maksimal, mahasiswa masih berminat terhadap referensi teks, selain dari pada itu e-book yang tersedia pada Univeristas Sriwijaya Palembang juga belum memenuhi kebutuhan mahasiswa. ${ }^{58}$ wawancara penulis dengan Rektor Universitas Sriwijaya Palembang juga menerangkan bahwa penggunaan e-book dikalangan mahasiswa maupun kalangan dosen juga belum maksimal, hanya mahasiswa dan dosen yang akrap dengan internet yang sering mengakses e-book. Padahal e-book lebih cepat didapat, dan tidak memakan waktu yang lama untuk mengaksesnya, walaupun $e$-book

56Wawancara dengan Anis Saggaff, Rektor Universitas Sriwijaya Palembang, 26 Februari 2019.

${ }^{57}$ Wawancara dengan Anita Rachmawati, Plt. Kepala Biro Universitas Sriwijaya Palembang, 26 Februari 2019.

580bservasi Universitas Sriwijaya Palembang, 26 Februari 2019. 
masih belum tersedia dengan maksimal, namun mahasiswa maupun dosen bisa mengakses di internet. ${ }^{59}$

Dalam perkembangannya, E-Book di dunia mahasiswa juga mengalami kendala seperti kesulitan untuk memiliki atau mengakses media elektronik untuk membaca $E$-Book karena tingkat ekonomi yang lebih rendah sehingga media pembaca bentuk elektronik seperti laptop, notebook maupun tablet menjadi barang yang masih cukup mahal bagi sebagian bagi mahasiswa. Hal ini semakin diperburuk dengan tingkat melek teknologi masih relatif belum merata bahkan di kalangan mahasiswa sendiri. Konsekuensinya tidak semua mahasiswa dapat mengakses internet untuk mendownload E-book. Jika lebih banyak buku yang diterbitkan melalui E-book tanpa tersedia versi buku cetaknya, maka informasi yang terdapat didalam E-book tidak akan dapat diakses oleh seluruh mahasiswa. Hanya kalangan yang akrab dengan internet yang dapat mengaksesnya, begitu juga dengan pemanfaatan e-jurnal.

Sedangkan sistem informasi manajemen yang diterapkan oleh universtas sriwijaya telah berjalan dengan baik, hal ini dapat penulis lihat telah tersedianya sistem informasi berbasis web, dimana mahasiswa bisa mengakses segala informasi, baik ditingkat universitas, fakultas maupun di tingkat program studi. Sistem pelayanan akademik juga sudah berbasis web sehingga mahasiswa dengan mudah bisa mengakses segala informasi akademik, nilai dan lain sebagainya. ${ }^{60}$ Wawancara penulis dengan Rektor Universitas Sriwijaya Palembang juga menejelaskan bahwa sistem informasi yang digunakan pada Universitas Sriwijaya ini sudah berbasis website, baik di tingkat universitas, fakultas sampai ke tingkat program studi. Untuk sistem informasi tingkat universitas dikelola oleh bagian rektorat, tingkat fakultas dikelola oleh tingkat fakultas dan untuk tingkat prodi dikelolah oleh program studi. 61

Wawancara dengan kepala biro Universitas Sriwijaya Palembang yang memberikan penjelasan bahwa saat ini Universitas Sriwijaya telah menggunakan dan menerapkan sistem informasi manajemen yang baik, dimana setiap informasi yang akan disapaikan kepada dosen maupun mahasiswa dapat di akses dengan mudah pada website yang disediakan oleh universitas, tingkat fakultas maupun di tingkat prodi, bukan hanya itu saja, pelayanan akademik juga dilakukan dengan menggunakan sistem informasi manajemen, hal ini dapat dilihat pada Website universitas Sriwijaya yang sudah terintegrasi dengan website fakultas, prodi, perpustakaan dan lembaga lainnya. ${ }^{62}$

\footnotetext{
${ }^{59}$ Wawancara dengan Anis Saggaff, Rektor Universitas Sriwijaya Palembang, 26 Februari 2019.

${ }^{60}$ Penelusuran melalui Website Universitas Sriwijaya Palembang, www.unsri.ac.id diakses pada tanggal 27 Februari 2019.

61Wawancara dengan Anis Saggaff, Rektor Universitas Sriwijaya Palembang, 27 Februari 2019.

62Wawancara dengan Anita Rachmawati, Plt. Kepala Biro Universitas Sriwijaya Palembang, 27 Februari 2019.
} 
Dari hasil wawancara, observasi dan hasil penelusuran penulis terhadap sistem informasi yang diterapkan Universitas Sriwijaya melalui Website universitas, fakultas, prodi dan sejumlah website lembaga yang ada pada Universitas Sriwijaya Palembang, maka dapat dipahami bahwa isu-isu global mengenai E-Learning, E-Book E-Journal dan Simpe Pendidikan sudah direspon dengan baik oleh Universitas Sriwijaya Palembang, dimana $E$ Learning, E-Book E-Journal dan sistem informasi Pendidikan telah diterapkan pada Universitas Sriwijaya Palembang, hanya saja pelaksanaannya belum maksimal. Sistem pembelajaran e-learning masih belum maksimal karena masih banyak proses pembelajaran dilakukan secara tatap muka, penggunaan $e$-book masih belum maksimal karena keterbatasan $e$-book yang disediakan oleh universitas, masih belum maksimalnya penggunaan $e$-jurnal dan ketersediaannya juga belum memadai, sedangkan sistem informasi pendidikan sudah berjalan dengan baik.

\section{Bibliografi}

Anonim, Al-Qur'an dan Terjemahan (Jakarta: Bumi Aksara, 2012).

Aan Prabowo dan Heriyanto, "Analisis Pemanfaatan Buku Elektronik (E- Book) oleh Pemustaka di Perpustakaan SMA Negeri 1 Semarang," Uurnal Ilmu Perpustakaan, Volume 2, Nomor 2, 2013).

Afifuddin, Dasar-Dasar Manajemen, (Bandung: Alfabeta, 2013).

Ahmad Barizi, (Ed), Pendidikan Integratif Akar Tradisi \& Integrasi Keilmuan Pendidikan Islam, (Malang: UIN-Maliki Press, 2011).

Ais Zakiyudin, Sistem Informasi Manajemen. (Jakarta: Mitra Wacana Media 2011).

Ali Mudlofir, Desain Pembelajaran Inovatif dari Teori Ke Praktek, (Jakarta: RajaGrafindo Persada, 2016).

Arif Nurochman, Strategi Digital untuk Meningkatkan Pemanfaatan E- Journal: Perspektif Pustakawan dan Perpustakaan, (Jurnal Visi Pustaka, Vol.13, 2011).

Azwar, Information Literacy Skills: Strategi Penelusuran Informasi Online.

B. Siswanto, Pengantar Manajemen, (Jakarta: Bumi Aksara 2011).

Daryanto, Media Pembelajaran, (Bandung: Satu Nusa, 2011).

Dewi Salma Prawiradilaga, dkk, Mozaik Teknologi Pendidikan E-learning, (Jakarta: Prenamedia group, 2013).

Diane Kresh, The Whole Digital Library Handbook, (Chicago: American Library Association, 2007).

Eduaksi, Pendidikan 4.0, Apa Itu?, https://eduaksi.com/pendidikan-4-0-apa/, diakses 04 April 2019 pukul 09.17 WIB.

Etty Andrianty, Pemanfaatan Jurnal Elektronis dan Kemuktahiran Informasi yang Disitir dalam Publikasi Primer", (Jurnal Perpustakaan Pertanian, 14, No. 2 2005).

Empi Effendy dan Hartono Zhuang, E-learning konsep dan aplikasi, (Yogyakarta: Andi, 2009).

Hamzah dan Nina Lamatenggo, Teknologi Komunikasi dan Informasi Pembelajaran, (Jakarta: PT Bumi Aksara, 2011).

Ida F Priyanto dan Sri P. Sedyaningsih, Buku Digital: Kajian Literatur Perkembangan dan Pengaruhnya pada Perpustakaan," (Jurnal Ilmu Perpustakaan dan Informasi., Vol.VIII, No. 2 Juli - Desember 2013). 
Lasa HS, Kamus Pustakawan Indonesia, (Yogyakarta: Pustaka Book Publisher, 2009).

Muhammad Alwan, Pengembangan Multimedia E-Book 3D Berbasis Mobile Learning Untuk Mata Pelajaran Geografi SMA Guna Mendukung Pembelajaran Jarak Jauh, (Jurnal At-Tadbir STAI Darul Kamal NW Kembang Kerang I, No. 2, 2018).

Munir, "Kontribusi Teknologi Informasi Dan Komunikasi (TIK) dalam Pendidikan di Era Globalisasi Pendidikan Indonesia", (Uurnal Pendidikan Teknologi Informasi Dan Komunikasi PTIK) Vol. 2 No. 2, Desember 2009).

Munir, Pembelajaran Jarak Jauh Berbasis Teknologi Informasi dan Komunikasi, (Bandung: Alfabeta, 2012).

Naimatil Jannah, Noor Fadiawati, and Lisa Tania, Pengembangan E-Book Interaktif Berbasis Fenomena Kehidupan Sehari-Hari Tentang Pemisahan Campuran,\|(Jurnal Pendidikan Dan Pembelajaran Kimia 6, No. 1, 2017.

Onisimus Amtu, Manajemen Pendidikan di Era Otonomi Daerah, (Bandung: Alvabeta, 2013).

Pendit, PutuLaxman, Perpustakaan Digital dari A sampai Z (Jakarta: Cita Karya Karsa, 2008).

Ranking Web of Universities edisi Januari 2018, dalam http://www.webometrics.info/en /Asia/indonesia\%20, diakses 10 April 2019.

Reitz, ODLIS: Online Dictionary of Library and Information Science, 564.

Rusman, dkk, Pembelajaran Berbasis Teknologi Informasi dan Komunikasi, (Jakarta: PT RajaGrafindo Persada, 2011).

Rusman, Model- Model Pembelajaran (Mengembangkan Profesionalisme Guru), (Jakarta : PT RajaGrafindo Persada, 2012), hal. 335.

Rosidin, Problematika Pendidikan Islam Perspektif (Maqasid Shari'ah, Maraji': Jurnal Studi Keislaman, Vol. 3, No. 1, September, 2016).

Sawitry, N. D, Pemanfaatan Koleksi E- Journal Bidang Ekonomi dan Bisnis oleh Civitas Akademika pada Perpustakaan Fakultas Ekonomi dan Bisnis (FEB) UIN Syarif Hidayatullah Jakarta. Skripsi, (Jakarta: UIN Syarif Hidayatullah, 2011).

Scott, George M. Prinsip-prinsi Sistem Informasi Manajemen. (Jakarta: PT.Rajagafindo Persada 2011).

Siswadi, Irman. Ketersediaan Online Journals di Perpustakaan Perguruan Tinggi". Visi Pustaka. Vol.10, No.2, 2008.

Suryadi, Manajemen Pendidikan, (Bandung: Alfabeta, 2011).

Syamsul Ma'arif, Revitalisasi Pendidikan Islam, (Yogyakarta: Graha Ilmu, 2007).

Wahyudi Kumorotomo dan Subando Agus Margono, Sistem Informasi Manajemen, (Yogyakarta: Gadja Mada University Press 2009).

Wawancara dengan Anis Saggaff, Rektor Universitas Sriwijaya Palembang, 26 Pebruari 2019.

Wina Sanjaya, Media Komunikasi Pembelajaran, (Jakarta: Prenamedia Group, 2012).

Wiji Suwarno, Library Life Style: Trend dan Ide Kepustakawanan, (Yogyakarta: Pustaka Nun Publishing, 2016).

Woodward, H., Cafe Jus: an Electronic Journals User Survey", Uournals of Digital Information, 1, No. 3 1998).

Yuberti, "Peran Teknologi Pendidikan Islam Pada Era Global", Uurnal Akademika, Vol. 20 No. 01, 2016).

Yusnimar, "E-Book Dan Pengguna Perpustakaan Perguruan Tinggi di Jakarta", (Jurnal Al-Maktabah 13, No. 1, 2014). 